JPSCR: Journal of Pharmaceutical Science and Clinical Research, 2020, 02, 121-135

DOI: $10.20961 /$ jpscr.v5i2.39048

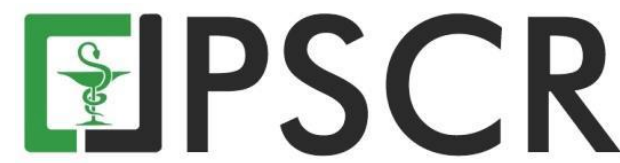

\title{
Analisis Kinerja Dalam Rangka Penyusunan Peta Strategi Instalasi Farmasi Rumah Sakit Airlangga Jombang dengan Pendekatan Balanced Scorecard
}

\author{
Dian Indrayanti*, Titik Sunarni dan Ika Purwidyaningrum \\ Fakultas Farmasi Universitas Setia Budi, Jl. Letjen Sutoyo, Jebres, Surakarta, Jawa Tengah, Indonesia, 57127 \\ *email korespondensi : dianindrayanti24@ gmail.com \\ Received 13 January 2020, Accepted 22 September 2020, Published 30 October 2020
}

\begin{abstract}
Abstrak: Instalasi Farmasi RS Airlangga selalu berupaya meningkatkan kualitas pelayanan, maka perlu dilakukan analisis kinerja dan pemetaan strategi Instalasi Farmasi. Tujuan penelitian mengevaluasi kinerja Instalasi Farmasi RS Airlangga ditinjau melalui empat perspektif balanced scorecard dan menentukan peta strategi berdasarkan hasil evaluasi kinerja. Penelitian ini merupakan non eksperimental rancangan deskriptif eksploratif. Pengumpulan data secara retrospektif dan concurrent berupa data kualitatif dan kuantitatif. Penelitian menggunakan indikator keempat perspektif balanced scorecard yang menentukan kinerja Instalasi Farmasi RS Airlangga dan kemudian menjadi dasar penyusunan peta strategi. Hasil penelitian perspektif keuangan nilai ITOR tahun 2018 mengalami penurunan dibanding 2016 dan 2017; nilai GPM dan GROS belum memenuhi standart. Perspektif bisnis internal menunjukan ketersediaan obat belum memenuhi standar, dispensing time memenuhi standar; Tingkat Pasien terlayani pasien perhari 95\%; pemberian label belum lengkap; pemberian informasi obat yang kurang lengkap; perspektif pertumbuhan dan pembelajaran menunjukkan semangat kerja dan kepuasan kerja karyawan pada kategori tinggi; pelatihan karyawan belum maksimal; produktifitas karyawan dalam kategori baik; pada perspektif pelanggan menunjukkan kepuasan pasien yang tinggi; keterjaringan pasien belum mencapai standar, tingkat pertumbuhan customer tahun 2018 mengalami peningkatan $8,06 \%$ dibanding 2017. Kesimpulan penelitian keempat perspektif dianalisis belum mencapai target yang ditetapkan. Instalasi farmasi diharapkan dapat meningkatkan kinerja sehingga membawa organisasi ke arah yang lebih baik sebelumnya.Pemetaaan strategi di instalasi farmasi RS Airlangga diperlukan perbaikan dari setiap indikator-indikator pengukuran kinerja dalam tiap perspektif untuk mendukung pencapaian strategi.
\end{abstract}

Kata kunci: Balance Scorecard; Peta strategi; Instalasi Farmasi; RS Airlangga

\begin{abstract}
Performance Analysis To Prepare Strategic Map Through Balanced Scorecard Approach On Pharmacy Installation At Airlangga Hospital Jombang. Pharmacy installation of Airlangga hospital always tries to improve service quality, accordingly necessary to do performance analysis and strategic mapping on pharmacy installation. Objective of this study was to evaluate pharmacy installation performance through balanced scorecard's four perspectives and determine strategic map based on the results the performance evaluation. Design this study was non-experimental explorative descriptive. Qualitative and quantitative data form retrospective and prospective data retrieved. This study used four perspective indicator of balanced scorecard that determined the performance on pharmacy installation at Airlangga hospital and prepared for strategic map. It resulted financial perspective, the value of ITOR in 2018 has decreased compared to 2016 and 2017; GPM and GROS values did not meet the standard. Internal business perspective showed that drug availability did not meet standards, dispensing time meets standards; The rate of patients served per day is 95\%; incomplete
\end{abstract}


labeling; providing incomplete drug information; growth and learning perspective showed that employee morale and job satisfaction were in the high category. Employee training was not optimal; employee productivity were in good category; customer perspective showed high patient satisfaction; patient networkability has not reached the standard, customer growth rate in 2018 had increased by $8.06 \%$ compared to 2017. Conclusion of this research, four perspectives analyzed did not reach the target. Hopefully that the pharmaceutical installation would improve its performance so that it can lead the organization to a better direction before. Strategy mapping at the Airlangga Hospital pharmaceutical installation requires improvement of each performance measurement indicator in each perspective to support the achievement strategy.

Keywords: Balanced Scorecard; Strategic Map; Pharmacy Installation; Airlangga Hospital

\section{Pendahuluan}

Peningkatan mutu pelayanan kesehatan sangat berhubungan erat dengan pelayanan kefarmasian. Kegiatan pelayanan kefarmasian di rumah sakit dilakukan Instalasi Farmasi Rumah Sakit. Peran farmasi di rumah sakit dalam aspek manajemen maupun pelayanan sangat penting dan saling terkait dengan sistem pelayanan di rumah sakit (Depkes, 2016). Kegiatan pelayanan kefarmasian mempunyai arti yang sangat penting di rumah sakit karena instalasi farmasi merupakan pelayanan penunjang medis yang menjadi cost centre atau pemberi pendapatan sebagian besar dan diharapkan instalasi farmasi dapat menjadi revenue centre bagi rumah sakit. Pencapaian mutu pelayanan kesehatan paripurna rumah sakit tidak akan terlepas dari peran instalasi-instalasi yang ada di rumah sakit termasuk instalasi farmasi. Dalam suatu Rumah Sakit, pelayanan kefarmasian dipusatkan di Instalasi Farmasi Rumah sakit (Depkes, 2014). Instalasi Farmasi Rumah Sakit bertanggung jawab mengembangkan pelayanan farmasi yang luas dan terkoordinasi dengan baik dan tepat, untuk memenuhi kebutuhan berbagai bagian atau unit diagnosis dan terapi, unit pelayanan keperawatan, staf medik dan rumah sakit keseluruhan untuk kepentingan pelayanan penderita yang lebih baik (Siregar \& Amalia, 2004).

Menurut (Mulyadi, 2014) dalam melipatgandakaan kinerja keuangan menjadi luar biasa secara berkesinambungan menggunakan pengukuran dengan metode balanced scorecard merupakan alat manajemen kontemporer yang didesain untuk meningkatkan kemampuan perusahaan oleh karena itu dengan memanfaatan balanced scorecard dalam pengelolaannya menjanjikan peningkatan signifikan kemampuan perusahaan dalam menciptakan kekayaan. Menurut Kaplan dan Norton (2004) pengukuran kinerja dalam organisasi masa depan yang dikenal dengan konsep BSC yang merupakan alat manajemen kontemporer (contemporary management tool) yang dapat digunakan oleh organisasi sebagai indikator perubahan lingkungan yang semakin kompleks.

Evaluasi kinerja yang belum rutin dilakukan disertai dengan kemampuan karyawan dalam berinovasi, pengalaman dalam bekerja, dan kompetensi keterampilan yang belum merata pada 
setiap staff di instalasi farmasi menyebabkan pencapaian kinerja yang dilakukan dalam proses bekerja tidak dapat diketahui dan diukur (Faramita, 2013). Menurut (Wahyuni et al, 2004) pengukuran kinerja dengan konsep balanced scorecard bertujuan untuk mengetahui pencapaian sasaran yang diorganisir dalam empat perspektif yaitu pembelajaran dan pertumbuhan, customer, proses bisnis internal, serta keuangan. Untuk itu perlu dilakukan penelitian yang menganalisis kinerja dengan pendekatan balanced scorecard, melalui empat perspektif tersebut. Pemetaan strategis berdasarkan BSC memprioritaskan hasil sasaran peningkatan sumber daya manusia sehingga akan meningkatkan kualitas pelayanan farmasi dan pertumbuhan pelanggan. Peningkatan jumlah pendapatan dan efisiensi biaya akan meningkatkan keuntungan instalasi farmasi (Amanda, 2015)

Kaitan antara kualitas pelayanan dan kepuasan pelanggan ialah bahwa kualitas pelayanan yang dipersepsikan merupakan suatu bentuk sikap, evaluasi menyeluruh dalam jangka panjang, sedangkan kepuasan menunjukkan ukuran transaksi tertentu karena kepuasan berlangsung dalam jangka pendek. Semakin tinggi tingkat kualitas pelayanan, maka semakin meningkat kepuasan pelanggan. Pernyataan tersebut menegaskan adanya hubungan yang erat antara kualitas pelayanan dengan kepuasan pelanggan (Parasuraman et al, 1998).

Salah satu pendekatan kualitas pelayanan yang banyak dijadikan sebagai acuan adalah model kesenjangan kualitas jasa dengan metode servqual (service quality) yang pada tahun 1980 dikembangkan oleh Parasuraman, Zeithaml dan Berry (Kotler dan Keller, 2006). Servqual dikembangkan atas adanya perbandingan dua faktor utama yaitu persepsi pelanggan atas layanan jasa yang nyata mereka terima (perceived service) dengan layanan yang mereka harapkan (expected service). Jika kenyataan atau kinerja lebih dari yang diharapkan maka layanan dapat dikatakan bermutu, sedangkan jika kenyataan kurang dari yang diharapkan, maka layanan dikatakan kurang bermutu. Apabila kenyataan sama dengan yang diharapkan, maka layanan disebut memuaskan. Servqual dapat digunakan sebagai metode pengukuran seberapa jauh perbedaan antara kenyataan atau kinerja dengan harapan pelanggan atas layanan yang mereka terima (Parasuraman et al, 1998). Instrumen servqual bermanfaat dalam melakukan analisis kesenjangan (gap), karena biasanya layanan/jasa bersifat intangible, kesenjangan komunikasi dan pemahaman antara karyawan dan pelanggan berdampak terhadap persepsi dan kualitas layanan.

Rumah Sakit Airlangga yang saat ini belum melayani pasien BPJS dan hanya melayani pasien umum dan asuransi swasta, dimana tuntutan pemerintah ke depannya semua rumah sakit wajib mengikuti program asuransi kesehatan BPJS. Rencana pengengembang rumah sakit dalam hal meningkatkan sarana dan prasarana terutama jumlah tempat tidur dan akan adanya proses kerjasama dibidang pelayanan kesehatan antara pihak asuransi kesehatan yaitu Badan 
Penyelenggara Jaminan Sosial (BPJS) kesehatan dengan pihak rumah sakit Airlangga akan mengakibatkan adanya perubahan lingkungan bagi instalasi farmasi. Pengukuran kinerja serta analisis lingkungan internal perlu dilakukan di instalasi farmasi rumah sakit Airlangga sebagai dasar untuk merumuskan strategi dalam menghadapi perubahan lingkungan sehingga tetap dapat mencapai visi dan misi organisasi belum pernah dilakukan sebelumnya.

Penelitian ini bertujuan sebagai analisis terhadap kinerja Instalasi Farmasi Rumah Sakit Airlangga dengan pendekatan BSC dari empat perspektif yaitu keuangan, bisnis internal, pertumbuhan dan pembelajaran dan kepuasan pelanggan yang berguna dalam menentukan peta strategi yang paling tepat demi meningkatkan kinerja Instalasi Farmasi. Penelitian ini memberikan hasil yang diharapkan dapat memberikan perubahan terhadap permasalahan kinerja maupun masalah lain yang terkait pelayanan Instalasi Farmasi Rumah Sakit Airlangga dan sebagai dasar pencapaian dan perbaikan kinerja yang berkesinambungan, serta menjadi koreksi bagi Instalasi Farmasi untuk meningkatkan mutu pelayanan farmasi.

\section{Metode}

Metode yang dilakukan untuk penelitian ini yaitu dengan penelitian non eksperimental menggunakan rancangan deskriptif eksploratif. Data penelitian diperoleh secara retrospektif dan concurrrent. Pengukuran kinerja dengan pendekatan BSC dengan empat perspektif yaitu perspektif keuangan dengan indikator ITOR, gross profit margin (GPM), dan growth ratio on sales (GROS), perspektif bisnis internal dengan indikator tingkat ketersediaan obat, rata-rata dispensing time, proporsi obat yang diberikan dengan label lengkap, tingkat medication error, pemberian informasi obat, perspektif pertumbuhan dan pembelajaran dengan indikator semangat kerja, kepuasan kerja karyawan, tingkat pelatihan karyawan, perspektif pelanggan dengan indikator kepuasan pelanggan, tingkat keterjaringan pasien dan pertumbuhan jumlah pelanggan.

Sumber data penelitian diperoleh dari data primer dan data sekunder. Sumber data primer diperoleh dengan alat kuisioner kepada pelanggan dan karyawan dan dilakukan observasi secara langsung. Sumber data sekunder ini berupa arsip kepegawaian Rumah Sakit, laporan penjualan bulanan dan laporan keuangan Instalasi Farmasi Rumah Sakit Airlangga dan data kunjungan pasien pada tahun 2016, 2017 dan 2018. Cara penelitian dan analisa data dilakukan sesuai dengan masing-masing indikator kinerjanya. Pengolahan data penelitian pada masingmasing indikator penelitian dapat dilihat pada tabel 1 .

Uji validitas dan reabilitas kuisioner dengan responden uji coba menggunakan jumlah minimal, yaitu 30 orang seperti yang disarankan oleh Sujarweni (2012) nilai r tabel dapat diperoleh melalui $\mathrm{r}$ tabel product moment pearson dengan $d f$ (degree of freedom $)=\mathrm{n}-2$, jadi $d f=30-2=28$, maka $r$ tabel $=0,312$. butir pertanyaan dikatakan valid jika nilai $r$ hitung $>\mathrm{r}$ tabel 
dapat dilihat dari corrected item total correlation. Sedangkan uji reliabilitas dilihat nilai Cronbach's Alpha, jika nilai Cronbach Alpha > 0,60 maka kontruk pertanyaan yang merupakan dimensi variable adalah reliabel. Dengan menggunakan instrument valid dan reliabel dalam pengumpulan data, diharapkan hasil penelitian menjadi valid dan reliabel karena instrument yang valid merupakan syarat untuk mendapatkan hasil penelitian yang valid dan reliabel. (Sugiyono, 2015)

Tabel 1. Pengolahan data penelitian pada masing-masing indikator penelitian berdasarkan 4 perspektif bersumber dari berupa arsip kepegawaian Rumah Sakit, laporan penjualan bulanan dan laporan keuangan Instalasi Farmasi Rumah Sakit Airlangga dan data kunjungan pasien pada tahun 2016, 2017 dan 2018.

\begin{tabular}{|c|c|c|c|c|}
\hline Perspektif & Indikator & $\begin{array}{c}\text { Alat dan Cara } \\
\text { Pengumpulan } \\
\text { Data } \\
\end{array}$ & Sampel & Teknik Analisis \\
\hline \multirow[t]{3}{*}{ Keuangan } & ITOR & Observasi & $\begin{array}{l}\text { Laporan Keuangan } \\
\text { Tahun 2016-2018 }\end{array}$ & Dihitung sesuai rumus \\
\hline & Gross Profit Margin & Observasi & $\begin{array}{l}\text { Laporan Keuangan } \\
\text { Tahun 2016-2018 }\end{array}$ & Dihitung sesuai rumus \\
\hline & Growth Ratio on Sales & Observasi & $\begin{array}{l}\text { Laporan Keuangan } \\
\text { Tahun 2016-2018 }\end{array}$ & Dihitung sesuai rumus \\
\hline \multirow[t]{6}{*}{$\begin{array}{l}\text { Proses Bisnis } \\
\text { Internal }\end{array}$} & $\begin{array}{l}\text { Tingkat Ketersediaan } \\
\text { Obat }\end{array}$ & Observasi & $\begin{array}{c}\text { Laporan Resep } \\
\text { Tahun 2016-2018 }\end{array}$ & $\begin{array}{l}\text { Dihitung \% item obat yang } \\
\text { diberikan }\end{array}$ \\
\hline & Dispensing Time & Observasi & 301 sampel & $\begin{array}{l}\text { Dihitung rata-rata } \\
\text { dispensing time resep }\end{array}$ \\
\hline & $\begin{array}{l}\text { Tingkat Pasien } \\
\text { Terlayani }\end{array}$ & Observasi & 301 sampel & $\begin{array}{l}\text { Dihitung jumlah } \\
\text { kedatangan pasien dengan } \\
\text { jumlah pelayanan }\end{array}$ \\
\hline & $\begin{array}{lcr}\text { Proporsi } & \text { Obat } & \text { yang } \\
\text { diberikan } & \text { label } & \text { dengan } \\
\text { lengkap } & & \\
\end{array}$ & Observasi & 301 sampel & $\begin{array}{l}\text { Dihitung dari Pemberian } \\
\text { label obat yang lengkap }\end{array}$ \\
\hline & $\begin{array}{ll}\text { Medication Error yang } \\
\text { disebabkan } & \text { oleh } \\
\text { prescribing error } & \\
\end{array}$ & Observasi & $\begin{array}{c}\text { Resep April-Mei } \\
2019\end{array}$ & $\begin{array}{l}\text { Adanya Kejadian } \\
\text { Medication Error }\end{array}$ \\
\hline & $\begin{array}{l}\text { Pemberian informasi } \\
\text { obat }\end{array}$ & Observasi & 301 sampel & $\begin{array}{l}\text { Dihitung dari pemberian } \\
\text { informasi obat pada saat } \\
\text { penyerahan }\end{array}$ \\
\hline \multirow{4}{*}{$\begin{array}{l}\text { Pertumbuhan } \\
\text { dan } \\
\text { Pembelajaran }\end{array}$} & Kepuasan Karyawan & Kuisioner & Seluruh Karyawan & Analisis Skor \\
\hline & Semangat Kerja & Kuisioner & Seluruh Karyawan & Analisis Skor \\
\hline & Pelatihan Karyawan & $\begin{array}{c}\text { Survey } \\
\text { Kepegawaian }\end{array}$ & Seluruh Karyawan & $\begin{array}{l}\text { Dihitung Proporsi } \\
\text { Karyawan yang mengikuti } \\
\text { pelatihan }\end{array}$ \\
\hline & $\begin{array}{l}\text { Tingkat Produktivitas } \\
\text { Karyawan }\end{array}$ & Observasi & Seluruh Karyawan & $\begin{array}{l}\text { Pengamatan perilaku pada } \\
\text { saat jam kerja }\end{array}$ \\
\hline \multirow[t]{3}{*}{ Pelanggan } & Kepuasan Pasien & Kuisioner & $\begin{array}{l}301 \text { sampel } \\
\text { dengan kunjungan } \\
\text { berulang }\end{array}$ & Analisis GAP \\
\hline & Keterjaringan Pasien & Observasi & $\begin{array}{l}\text { Data Jumlah pasien } \\
\text { dan resep di } \\
\text { instalasi farmasi di } \\
\text { Tahun } \\
\text { 2016- } 2018 \\
\end{array}$ & $\begin{array}{l}\text { Dihitung \% resep rawat } \\
\text { jalan yang dibeli di } \\
\text { instalasi farmasi }\end{array}$ \\
\hline & $\begin{array}{l}\text { Peningkatan } \\
\text { Customer }\end{array}$ & Observasi & $\begin{array}{l}\text { Data Jumlah } \\
\text { Pasien Tahun } \\
\text { 2016-2018 } \\
\end{array}$ & $\begin{array}{l}\text { Dihitung \% peningkatan } \\
\text { jumlah customer }\end{array}$ \\
\hline
\end{tabular}


Kuisioner kepuasan gap lima dimensi mengacu pada kuisioener SERVQUAL oleh Parasuraman (1998), pada kuisioner semangat kerja mengacu berdasarkan skala psikologi Azwar (2014), kepuasan kerja karyawan mengacu pada Harsono (2010). Semua hasil kuesioner dianalisis menggunakan skala Likert. Setelah dilakukan penilaian dengan menggunakan skala likert, untuk kuisioner selanjutnya dilakukan analisis nilai dari jawaban responden yang dijumlahkan kemudian dihitung nilai rata-ratanya. Nilai rata-rata tersebut selanjutnya dihubungkan dengan tingkat hasil semangat kerja karyawan, kepuasan kerja karyawan dan kepuasan pasien. Range skor kuisioner dapat dilihat pada Tabel 2 berdasarkan pada skala likert.

Tabel 1.Range skor kepuasan pasien, kepuasan karyawan berdasarkan mengacu pada kuisioener SERVQUAL oleh (Parasuraman 1998) dan semangat kerja karyawan berdasarkan skala psikologi Azwar (2014).

\begin{tabular}{cc}
\hline Nilai Range Skor & Kriteria Penilaian Kepuasan \\
\hline $1,0 \leq \mathrm{x} \leq 1,75$ & Sangat Rendah \\
$1,75 \leq \mathrm{x} \leq 2,5$ & Rendah \\
$2,5 \leq \mathrm{x} \leq 3,25$ & Tinggi \\
$3,25 \leq \mathrm{x} \leq 4,0$ & Sangat Tinggi \\
\hline
\end{tabular}

\section{Hasil dan Pembahasan}

\subsection{Perspektif Keuangan}

Penilaian kinerja berdasarkan perspektif keuangan dilihat dari beberapa indikator yaitu inventory turn-over ratio (ITOR), gross profit margin (GPM), groos ratio on sales (GROS) dalam pengukuran ini data diperoleh dari laporan tahunan bagian keuangan rumah sakit keuangan pada tahun 2016, 2017 dan 2018. Hasil Perhitungan dapat dilihat pada tabel 3.

Tabel 3. Hasil Perhitungan ITOR, GPM, dan GROS di Instalasi Farmasi RS Airlangga Tahun 2016, 2017 dan 2018.

\begin{tabular}{ccccc}
\hline Parameter & \multicolumn{3}{c}{ Tahun } & Standar \\
\cline { 2 - 5 } & $\mathbf{2 0 1 6}$ & $\mathbf{2 0 1 7}$ & $\mathbf{2 0 1 8}$ & \\
\hline ITOR & $9,61 \mathrm{kali}$ & $8,22 \mathrm{kali}$ & $7,94 \mathrm{kali}$ & $8-12 \mathrm{kali}$ \\
\hline GPM & $17,06 \%$ & $12,94 \%$ & $14,48 \%$ & $20-33 \%$ \\
\hline GROS & $22,50 \%$ & $-22,54$ & $5,04 \%$ & $\geq 10 \%$ \\
\hline
\end{tabular}

Nilai ITOR masuk pada nilai standar pada tahun 2016 dan 2017 dan nilai ITOR pada tahun 2018 berada pada nilai standard minimal (Tabel 3). Hal ini menunjukkan perputaran persediaan di IFRS masih kurang efisien. Selain itu, terjadi penurunan nilai ITOR pada tahun 2018 dibandingkan dengan nilai ITOR tahun 2017. Hal ini menunjukkan adanya peningkatan persediaan yang tidak sebanding dengan peningkatan penjualan. Nilai Gross Profit Margin (GPM) tersebut berada dibawah standar nilai GPM yang ideal yaitu berkisar 20-33\%. Menurut Seto (2017) standar groos profit margin yang ideal adalah sebesar 20-33\%. Hal ini menunjukkan bahwa penjualan di Instalasi Farmasi RS Airlangga masih perlu ditingkatkan. Nilai GROS pada tahun 2017 dan peningkatan di tahun 2018 nilai GROS tersebut belum masuk standar nilai GROS di Indonesia. Menurunnya GROS pada tahun 2017 dibandingkan dengan tahun 2016 yaitu RS.Airlangga adalah 
rumah sakit umum swasta yang belum mengikuti program pemerintah yaitu program BPJS, karena peningkatan penggunaan BPJS di rumah sakit yang bekerjasama dengan BPJS dimana pertumbuhan penjualan pada tahun 2017 mengalami penurunan yaitu nilai GROS -22,54\% dibandingkan pada tahun 2016. Pada tahun 2018 ada peningkatan nilai GROS sebesar 5,04\%, peningkatan ini di karenakan pihak manajemen dari RS meningkatkan kerjasama di bidang asuransi swasta yang tidak menggunakan BPJS.

\subsection{Perspektif Bisnis Internal}

Penilaian kinerja karyawan berdasarkan perspektif proses bisnis internal Instalasi Farmasi RS Airlangga menggunakan beberapa indikator, meliputi tingkat ketersediaan obat, dispensing time, proporsi obat yang diberikan label dengan lengkap, tingkat medication error yang disebabkan oleh prescribing error, dan pelayanan pemberian informasi obat (PIO). Data diambil di Instalasi Farmasi Rawat Jalan RS Airlangga.

Ketersediaan obat di IFRS tidak mencapai 100\% dengan rata-rata $97.28 \%$ diantaranya adalah karena obat kosong di PBF, obat kosong di gudang farmasi, obat non formularium. Alasan utama obat tidak terlayani ialah karena obat non formularium yang dikarenakan kurangnya kepatuhan dokter dalam peresepan obat sesuai formularium, sehingga obat yang diminta tidak dapat dilayani.

Rata-rata Dispensing time di instalasi farmasi untuk obat racikan diperoleh 24 menit, sedangkan untuk obat non racikan 18 menit. Berdasarkan Permenkes RI Nomor 129 Tahun 2008 tentang Standar Pelayanan Minimal (SPM) Rumah sakit, standar waktu tunggu rawat jalan untuk pelayanan resep untuk obat dengan perlakuan racikan adalah $\leq 60$ menit dan untuk obat tunggal atau tidak mendapat perlakuan racikan adalah $\leq 30$ menit. Rata-rata Dispensing time telah memenuhi standar Permenkes. Waktu tunggu / antrian juga akan mempengaruhi kinerja dan kepuasan pasien (Liza, 2001). Indikator rata-rata waktu penyediaan obat dapat menggambarkan kinerja organisasi secara keseluruhan, karena kecepatan pelayanan obat sangat dipengaruhi oleh: lay out pelayanan, beban kerja karyawan, ketersediaan obat di unit pelayanan, teknis dan cara penyimpanan, tingkat pengetahuan dan keterampilan karyawan serta komitmen dan rasa tanggung jawab karyawan terhadap pekerjaan (WHO, 1993)

Tingkat Pasien Terlayani rata-rata perharinya sebesar 95\% dapat dikatakan IFRS mampu menangani dengan baik antrian pasien sebanyak 95\% perharinya atau antrian yang tidak terlayani sebanyak 5\% perharinya. Standar pelayan sehingga dikatakan cukup baikan minimal rumah sakit untuk tingkat pasien terlayani $\geq 90 \%$ sehingga dapat dikatakan Instalasi Farmasi RS Airlangga telah cukup baik dalam menangani antrian pasien karena mendekati $100 \%$.

Kelengkapan pelabelan etiket pada obat sudah cukup lengkap ditulis,meliputi tanggal resep, nomor resep, nama pasien, nama obat, indikasi, aturan pakai, sebelum/sesudah makan, 
jumlah obat, dan ED (Kadaluarsa). Komponen yang kurang lengkap terdapat pada penulisan nomor RM di etiket dengan persentase sebesar $37 \%$. Dikarenakan proses pembuatan etiket masih dilakukan manual dengan mengetik, dan waktu yang digunakan untuk mengetik etiket cukup lama.

Pengukuran tingkat medication error yang disebabkan oleh prescribing error diperoleh dengan melakukan observasi resep selama bulan April-Mei 2019. Pada observasi secara langsung ditemukan tidak adanya kejadian medication error yang disebabkan oleh prescribing error. Upaya pencegahan yang dapat dilakukan untuk meminimalkan insiden medication error diantaranya yaitu dilakukannya review semua farmakoterapi yang terjadi oleh apoteker maupun oleh tenaga profesi terkait obat, mendisiplinkan kelengkapan permintaan obat, memastikan kejelasan instruksi obat.

Pemberian informasi obat yang disampaikan oleh petugas pelayanan di Instalasi Farmasi pada saat menyerahkan obat berupa informasi mengenai nama obat generik atau nama dagang, indikasi atau kegunaan, dosis obat, aturan pakai atau aturan minum, efek samping dari obat, lama penggunaan dan cara penyimpanan. Waktu rata-rata pemberian informasi obat yaitu 113 detik. Hasil pemberian informasi dapat dilihat pada Tabel 4.

Tabel 4. Pemberian Informasi Obat di Rawat Jalan Instalasi Farmasi Rumah Sakit Airlangga.

\begin{tabular}{lc}
\hline Pemberian Informasi Obat & Persentase kelengkapan (\%) \\
\hline Nama Obat & 100 \\
Indikasi & 100 \\
Dosis & 99,34 \\
Aturan Pakai & 100 \\
Efek Samping & 75,08 \\
Lama Penggunaan & 69,94 \\
Cara Penyimpanan & 57,14 \\
Rata-Rata & $\mathbf{8 5 , 8 6}$
\end{tabular}
Rata-Rata 85,86

Pemberian informasi obat belum 100\%. Pemberian informasi obat merupakan bagian dari pelayanan farmasi. Dimungkinkan bahwa kualitas pelayanan informasi obat berpengaruh terhadap kepuasan pasien sehingga memberikan kemudahan pasien dalam mematuhi penggunaan obat.

\subsection{Perspektif Pertumbuhan dan Pembelajaran}

Penilaian kinerja berdasarkan perspektif pertumbuhan dan pembelajaran Instalasi Farmasi Airlangga menggunakan beberapa indikator, meliputi kepuasan karyawan, semangat kerja karyawan dan pelatihan karyawan.

Dengan menggunakan kuisioner dengan 7 indikator pertanyaan diantaranya : uang jasa kefarmasian (take home pay), pekerjaan dan tugas harian, pengawasan, hubungan dengan atasan langsung kepala Instalasi Farmasi, promosi peningkatan jabatan, waktu jam kerja dan 
tugas kerja para karyawan. Hasil penelitian pada kepuasan kerja karyawan menunjukan ratarata 2,91 yang mempunyai arti berada pada tingkat puas. Dengan range skor $2,5 \leq \mathrm{x} \leq 3,25$ mempunyai skor kepuasan tinggi.

Pada semangat kerja Analisis terhadap data tersebut menggunakan perskalaan terhadap item pernyataan yang bersifat positif (favourable) dan pernyataan yang bersifat negatif (unfavourable.) Hasil menunjukan rata-rata 3,19 yang mempunyai arti berada pada tingkat tinggi dengan semangat kinerja yang tinggi di instalasi farmasi sehingga hal ini akan berpengaruh pada kinerja Instalasi farmasi RS Airlangga karena dengan mempunyai semangat kerja yang baik seringkali seiring dengan adanya peningkatan loyalitas petugas terhadap perusahaan khususnya di instalasi farmasi (Rao C and Rao K, 2009). Semangat kerja paling tinggi pada pernyataan memikirkan cara untuk hasil kerja yang lebih baik. Menurut (Satibi, 2015), karyawan dengan semangat kinerja yang tinggi didukung dengan adanya kesesuaian job desk atau tugas harian dari masing-masing karyawan dengan tingkat pendidikan yang berbeda dan keahlian yang dimiliki. Selain itu tingkat semangat kerja yang tinggi juga dipengaruhi pendapatan yang diterima karyawan yang layak dan sesuai dengan tugas yang dikerjakan, wewenang yang dimiliki, serta jabatan.

Persentase pelatihan karyawan tiap tahunnya mengalami peningkatan terlihat bahwa pada tahun 2016 sebesar $100 \%$, tahun 2017 sebesar $100 \%$ dan tahun 2018 sebesar 22\%. Instalasi farmasi dan divisi diklat perlu adanya target setiap tahun untuk jumlah pelatihan bagi karyawan, pelatihan bisa dilakukan secara internal dengan melakukan pelatihan didalam rumah sakit maupun eksternal dengan mengikuti pelatihan yang diadakan pihak ketiga. Para karyawan farmasi dilakukan rolling secara bergantian untuk mendapat pelatihan sehingga jumlah karyawan yang telah mendapat pelatihan di dalam maupun diluar merata.

Tingkat produktifitas karyawan IFRS dengan produktif langsung sebesar 75\%. Menurut (Sulistyaningrum et al, 2016) karyawan yang memanfaatkan waktu kerja produktif secara langsung dengan nilai 75\% dapat dikatakan baik. Selain tingkat produktifitas secara langsung, karyawan di instalasi farmasi juga melakukan kegiatan produktifitas secara tidak langsung. Tingkat produktifitas karyawan menggambarkan budaya kerja, dan rendah atau tinggi tikngkat produktifitas memberikan petunjuk tentang beban dan volume kerja karyawan. Semangat kerja karyawan ini dipengaruhi salah satunya oleh beban kerja.

\subsection{Perspektif Pelanggan}

Penilaian kinerja berdasarkan perspektif pelanggan Instalasi Farmasi RS Airlangga menggunakan beberapa indikator, meliputi kepuasan pasien, keterjaringan pasien, dan peningkatan jumlah customer. 
Pada penelitian ini kepuasan pelanggan dengan metode Servqual diketahui nilai 5 dimensi kualitas jasa sebagai berikut : (1) Tangibles (berwujud), yaitu penampilan fasilitas fisik, peralatan, personel dan alat komunikasi, (2) Realibility (Keandalan), yaitu kemampuan untuk melaksanakan jasa yang dijanjikan secara terpercaya dan akurat, (3) Responsiveness (Daya tanggap), yaitu kemauan untuk membantu pelanggan dan memberikan pelayanan terbaik. (4) Assurance (Jaminan), yaitu pengetahuan dan kesopanan karyawan serta kemampuan mereka untuk menimbulkan kepercayaan dan keyakinan, (5) Emphaty (Empati), yaitu kesediaan untuk peduli, memberikan perhatian pribadi kepada pelanggan. Analisis gap dilakukan untuk mengetahui apakah ada perbedaan signifikan antara skor sampel kinerja dan skor sampel harapan. Selisih tersebut dihitung dari skor kuesioner pada massing-masing dimensi. Analisis gap menggunakan uji Wilcoxon dengan metode statistik non parametrik. Kriteria ujinya adalah skor kinerja dan skor harapan berbeda secara signifikan bila nilai signifikannya lebih kecil dari 0,05 sebaliknya tidak ada perbedaan yang nyata bila nilai signifikannya lebih besar dari 0,05 . Berdasarkan uji Wilcoxon menunjukkan nilai sigifikansinya sebesar 0,893 nilai lebih besar dari 0,05 sehingga dapat disimpulkan tidak ada perbedaan signifikan antara kinerja dan harapan maka hal ini berarti bahwa kepuasan pasien terhadap kinerja pelayanan Instalasi Farmasi RS Airlangga sudah terpenuhi.

Keterjaringan pasien menunjukan rata-rata $76.27 \%$ disebabkan banyaknya pasien tidak membeli resep di IFRS melainkan langsung menebusnya di apotek luar dikarenakan menghindari antrian resep khususnya pada pasien rawat jalan dan juga kemungkinan disebabkan karena ketidaktersediaan obat.

Persentase rata-rata peningkatan jumlah customer di IFRS pada tahun 2017 sebesar 8,43\% mengalami penurunan jumlah customer. Jumlah customer dilihat berdasarkan jumlah resep yang masuk di instalasi farmasi. Penurunan jumlah resep pasien tentu saja akan mempengaruhi penghasilan Rumah Sakit, mengingat bahwa Instalasi Farmasi merupakan revenue centre dan cost centre. Penurunan jumlah resep pasien kemungkinan disebabkan oleh makin banyaknya pengobatan dengan menggunakan BPJS, sedangkan RS Airlangga belum melakukan kerjasama dengan BPJS.

\subsection{Peta Strategi Instalasi Farmasi}

Berdasarkan permasalahan dan hasil penelitian pada indikator yang ada dalam 4 perspektif balanced scorecard maka akan menjadi dasar dalam penyusunan peta strategi yang dapat dijalankan Instalasi Farmasi RS Airlangga untuk meningkatkan kinerja Instalasi Farmasi RS Airlangga (Gambar 1).

Pada perspektif pengukuran pembelajaran dan pertumbuhan pada penelitian ini yaitu kepuasan karyawan, semangat kerja dan tingkat produktifitas karyawan di instalasi farmasi. 
Untuk perspektif pembelajaran dan pertumbuhan di Rumah Sakit Airlangga sudah baik. Hasil menunjukan kepuasan karyawan secara keseluruhan dari pengukuran yang telah diukur. Berdasarkan penelitian lain bahwa untuk peningkatkan kualitas dari sumber daya manusia sebagai karyawan instalasi farmasi yang dimiliki tanpa melupakan kesejahteraan karyawan agar timbal balik yang diberikan kepada pelanggan menjadi baik karena sudah mendapatkan kesejahteraan baik dari perusahaan (Wicaksono, 2010).

Pendidikan dan pelatihan yang bisa diperoleh diluar seperti mengikuti seminar, workshop, pelatihan atau di dalam rumah sakit seperti in house training bagi karyawan diantaranya mengenai pelatihan yang terkait informasi kefarmasian terbaru. Dengan adanya upaya peningkatan pengetahuan tersebut diharapkan dapat meningkatkan wawasan maupun pengetahuan dan ketrampilan karyawan sehingga outcome (hasil) yang diterima yaitu dapat meningkatkan kinerja pelayanan Instalasi Farmasi yang berdampak pada kepuasan pasien terhadap pelayanan yang berkualitas.

Pada perspektif pengukuran proses bisnis internal, banyak strategi-strategi yang harus dilakukan yaitu dengan meningkatnya kualitas pelayanan kesehatan yang menjadi sasaran strategisnya. Peningkatan kualitas pelayanan dapat dilakukan dengan beberapa cara diantaranya penurunan dispensing time, penurunan Tingkat Pasien Terlayani, peningkatan pelayanan informasi obat, pelabelan yang lengkap, peningkatan ketersediaan obat, penurunan insiden medication error akibat kesalahan prescribing. Mempertahankan waktu dispensing time dapat dilakukan dengan melakukan penambahan loket penerimaan dan penyerahan obat, loket penerimaan dan penyerahan obat yang berdampingan, penambahan SDM dan komputer penginput data resep, meningkatkan ketersediaan obat dengan memaksimalkan peran KFT (Komite Farmasi dan Terapi) di rumah sakit sehingga mengurangi waktu petugas dalam menulis copy resep, mengkonfirmasi sediaan kepada dokter penulis resep maupun menunggu kekurangan obat yang datang dari luar instalasi farmasi, adanya peningkatan komitmen dan tanggung jawab petugas saat melakukan dispensing time sehingga karyawan tidak melakukan kegiatan non produktif lainnya, adanya peningkatan pelanggan dan penurunan waktu penyediaan obat tentunya akan menurunkan Tingkat Pasien Terlayani pasien.

Pengoptimalan PIO dapat dilakukan dengan cara meningkatkan kompetensi karyawan khususnya dalam pemberian informasi terkait obat yaitu aspek farmakologi, farmakoterapi dan farmasi klinis. Pelabelan obat yang lengkap akan mengurangi resiko kesalahan pemberian obat terutama akan membantu pasien dalam penggunaan obat secara tepat. Peningkatan ketersediaan obat dapat meningkatkan kualitas pelayanan karena pelanggan akan selalu merasa obat-obatan yang mereka perlukan tersedia di Instalasi Farmasi. Ketersediaan obat dipengaruhi oleh kepatuhan penulis resep terhadap formularium rumah sakit sehingga Instalasi Farmasi dapat 
menyediakan kebutuhan obat kepada pasien dengan maksimal akan meningkatkan penjualan. Peningkatan ketersediaan obat juga berpengaruh dalam peningkatan keterjaringan pelanggan. Penurunan persentase medication error yang disebabkan prescribing error dapat dilakukan dengan cara membuat standarisasi prosedur seperti menetapkan standar prosedur operasi (SPO) dan adanya otomatisasi atau dukungan teknologi informasi di Instalasi Farmasi misalnya adanya program yang memungkinkan terdeteksinya kesalahan resep sehingga meminimalisir medication error seperti e-prescribing.

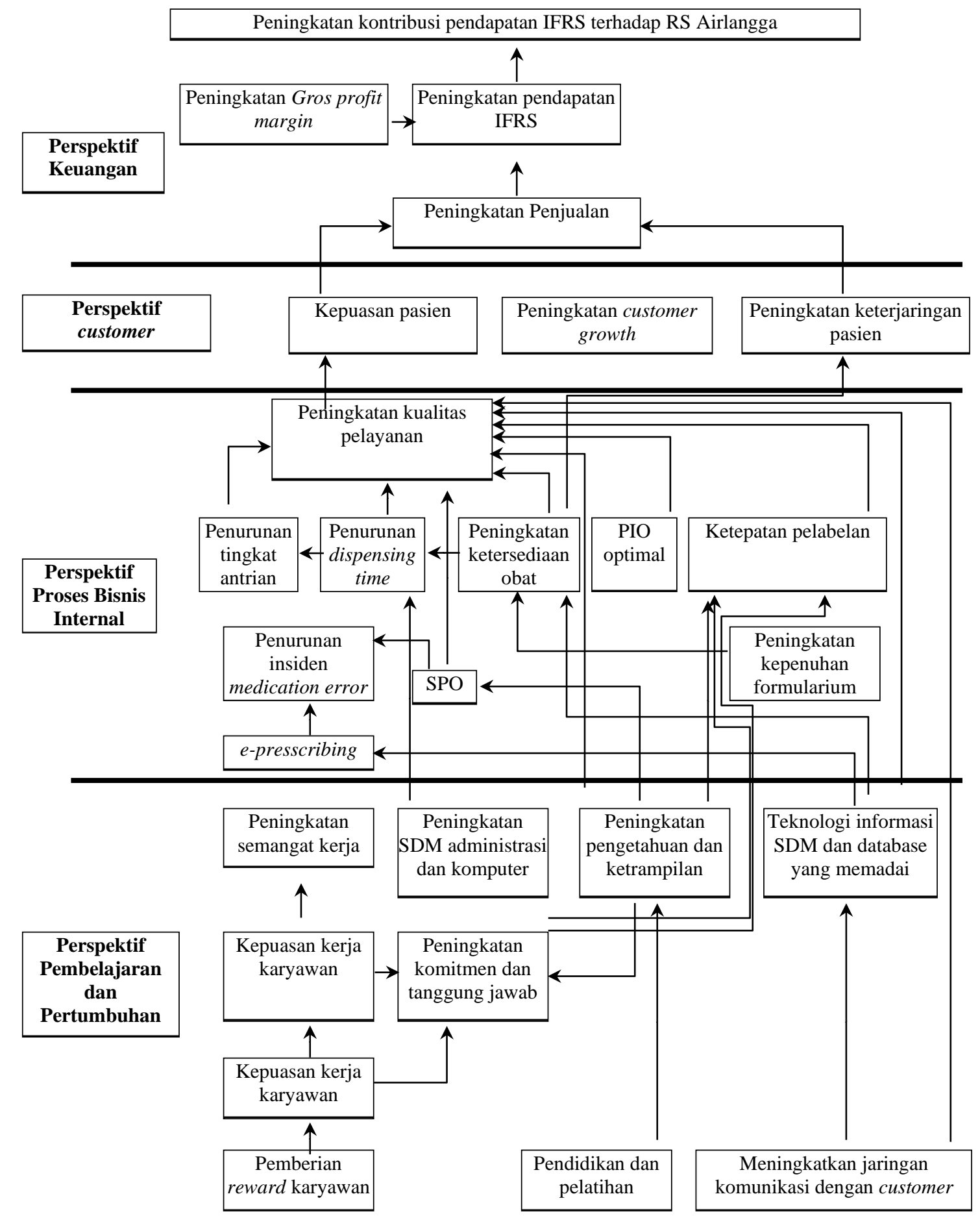

Gambar 1. Peta Strategi Instalasi Farmasi Rumah Sakit Airlangga 
Melalui usaha-usaha dalam peningkatan kualitas pelayanan pada perspektif proses bisnis internal maka diharapkan akan tercapai sasaran strategis pada perspektif pelanggan yaitu meningkatnya kepuasan pasien, keterjaringan pasien dan meningkatnya jumlah pelanggan. Dengan kondisi rumah sakit Airlangga yang tidak melakukan kerjasama dengan BPJS sehingga pasien yang melakukan pemeriksaan hanya pasien umum atau pasien dengan asuransi swasta. Bila kepuasan pasien meningkat maka tingkat keterjaringan customer juga meningkat, selain itu adanya word of mouth, maka dapat menambah customer baru bagi Instalasi Farmasi, sehingga customer growth akan meningkat. Tingkat keterjaringan pasien sangat dipengaruhi oleh tingkat ketersediaan obat, sehingga dengan tercapainya peningkatan ketersediaan obat di Instalasi Farmasi, maka tingkat keterjaringan customer juga akan meningkat dan mempengaruhi pada perspektif keuangan yaitu peningkatan tingkat penjualan.

Peningkatan penjualan akan meningkatkan pendapatan Instalasi Farmasi. Dalam peningkatan pendapatan Instalasi Farmasi juga diperlukan upaya meningkatkan gross profit margin yaitu dengan meningkatkan harga pokok penjualan yang dipengaruhi oleh peningkatan penjualan dan persediaan. Nilai penjualan yang meningkat akan berpengaruh pada peningkatan groos profit margin.

\section{Kesimpulan}

Dari hasil penelitian, pengamatan dan wawancara tentang analisis kinerja di Instalasi Farmasi Rumah Sakit Airlangga dengan menggunakan pendekatan Balanced Scorecard mencakup empat perspektif. Kinerja perspektif keuangan menunjukkan adanya penurunan nilai ITOR, GPM dan GROS dimana nilai ini tidak memenuhi standar. Di tahun 2016, 2017, dan 2018 mengalami keuangan yang fluktuatif dimana perputaran persediaan di instalasi masih kurang efisien. Kinerja perspektif proses bisnis internal di Instalasi Farmasi Rawat Jalan RS Airlangga menunjukkan hasil yang belum memenuhi standar yaitu tingkat ketersediaan obat, pemberian label obat dengan lengkap, pemberian informasi obat, Untuk rata-rata dispensing time, tingkat pasien terlayani pasien, tingkat medication error sudah memenuhi standar. Kinerja perspektif pembelajaran dan pertumbuhan menunjukan tingkat produktifitas kerja karyawan yang baik, hasil nilai yang tinggi pada semangat kinerja karyawan, kepuasan kinerja karyawan; pelatihan karyawan menurun setiap tahunnya. Kinerja perspektif pelanggan menunjukan kepuasan pasien yang positif dan memperoleh hasil yaitu tidak terdapat perbedaan yang signifikan antara tingkat kualitas pelayanan kesehatan yang diterima dan tingkat kualitas pelayanan kesehatan yang diharapkan; keterjaringan pasien dan peningkatan jumlah customer belum memenuhi standar.

Berdasarkan penelitian hasil analisis kinerja IFRS Airlangga dengan pendekatan Balanced Scorecard dari pengukuran empat perspektif yaitu pada perspektif keuangan 
menunjukkan masih kurang efisien, pada perspektif proses bisnis internal hasil yang diperoleh belum memenuhi standar, pada hasil perspektif pembelajaran dan pertumbuhan menunjukan hasil yang baik dan hasil yang cukup baik juga diperoleh pada penilaian perspektif pelanggan.

\section{Ucapan Terima Kasih}

Penulis ucapkan terima kasih kepada Rumah Sakit Airlangga Jombang, Universitas Setia Budi dan Staf Instalasi Farmasi Rumah sakit Airlangga Jombang yang membantu di dalam pengumpulan data pengerjaan hingga mendapatkan hasil penelitian.

\section{Deklarasi Konflik Kepentingan}

Semua penulis menyatakan tidak ada konflik kepentingan terhadap naskah ini.

\section{Daftar Pustaka}

Anggraini, K. (2011). Analisis Kinerja dalam Rangka Penyusunan Peta Strategi Instalasi Farmasi RSUD dr. Agoesdjam Ketapang dengan Pendekatan Balanced Scorecard. Tesis, Program Pascasarjana Universitas Gadjah Mada, Yogyakarta.

Amanda, M. (2015). Analisis Kinerja dan Pemetaan Strategi Instalasi Farmasi Menggunakan Balanced Scorecard. Tesis, Program Pascasarjana Universitas Gadjah Mada, Yogyakarta Azwar S. (2014). Penyusunan Skala Psikologi. Yogyakarta: Pustaka Pelajar

Depkes.RI. (2014). Peraturan Menteri Kesehatan Republik Indonesia Nomor.56 Tentang Perizinan dan Klasifikasi Rumah Saikit. Departemen Kesehatan Republik Indonesia. Jakarta

Depkes.RI. (2016). Peraturan Menteri Kesehatan Republik Indonesia Nomor.72 Tentang Standar Pelayanan Rumah Saikit. Departemen Kesehatan Republik Indonesia. Jakarta

Faramita, R. (2013). Analisis Kinerja Instalasi Farmasi RSUD KRT. Setjonegoro Kabupaten Wonosobo Jawa Tengah dengan Pendekatan Balanced scorecard. Tesis, Universitas Setia Budi Surakarta, Surakarta.

Harsono, S.B.M. (2010). Analisis Kinerja Instalasi Farmasi Rumah Sakit Medika Mulya Wonogiri dengan Pendekatan Balanced Scorecard. Tesis, Universitas Setia Budi, Surakarta.

Kaplan, R.S., dan Norton, D.P. (2004). Measuring the Strategic Readliness Of Intengible Assets. Harvard Bussines, 139

Kotler, P., Keller, K.L. (2006). Marketing Management. Edisi 12. New Jersey: Pearson Education Inc.

Liza. (2001). Pengukuran Kinerja Apotek Koperasi Pegawai RSUP dr. Hasan Sadikin Bandung dengan pendekatan Balanced Scorecard. Tesis, Universitas Gadjah Mada, Yogyakarta.

Mulyadi. (2014). Sistem Terpadu Pengelolaan Kinerja Personel Berbasis Balanced Scorecard. Unit Penerbit dan Percetakan Sekolah Tinggi Ilmu Manajemen YKPN, Yogyakarta.

Parasuraman A., Zeithamil, Valarie A., Berry Leonard L. (1998). SERVQUAL: A MultipleItem Customer Perception of Service Quality. Journal of Retailing, 64:1

Rao, C. M., and Rao, K. P., (2009). Inventory Turnover Ratio as A Supply Chain Performance Measure. Serbian Journal of Management, 4 (I): 41-50.

Satibi. (2015). Manajemen Obat di Rumah Sakit. Yogyakarta: UGM Press.

Seto, Soerjono. (2017). Manajemen Farmasi Dasar-Dasar Akutansi untuk Apotek, PBF dan Industri Farmasi. Airlangga University Press, Surabaya

Siregar, C.J. P. dan Lia, A. (2004). Farmasi Rumah Sakit Teori dan Penerapan. Cetakan Pertama, Penerbit Buku Kedokteran EGC, Jakarta.

Sugiyono. (2015). Statistika untuk Penelitian, Cetakan 26, Penerbit Alfabeta, Jakarta

Sujarweni, V.W. (2012). SPSS Untuk Paramedis, Cetakan 1, Penerbit Gava Media, Yogyakarta. 
Sulistyaningrum I. H., Wirastuti K., Afif MM. (2016). Performance Appraisal in Pharmacy Department Sultan Agung Islamic Hospital by Balanced Scorecard Approach on Internal Business Perspectives. Sains Medika: Jurnal Kedokteran dan Kesehatan, 7(1), pp. 21-24 Wahyuni, E., Tomo, H.S., Tangkilisan H.N.S. (2004). Balanced Scorcard untuk Manajemen Publik, YPAPI, Yogyakarta.

Wicaksono. (2010). Balanced scroecard pada Rumah Sakit Umum Daerah (RSUD) Blambangan Kabupaten banyuwangi. Tesis, Universitas Gadjah Mada, Yogyakarta. WHO. (1993). How to Investigate Drug Use in Health Facilities, WHO, Geneva.

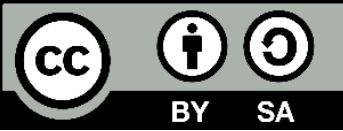

C 2020 by the authors. Submitted for possible open access publication under the terms and conditions of the Creative Commons Attribution-ShareAlike 4.0 International (CC BY-SA 4.0) license (https://creativecommons.org/licenses/by-sa/4.0/). 